\title{
The Application of Game Teaching Method in the Teaching of English
}

\section{Economy}

\author{
Peng Xuejuan ${ }^{1}$ \\ ${ }^{1}$ Department of Trade and Economics, Qinghai University School of Finance and Economics, \\ Qinghai, 810016, China
}

Keywords: Game teaching, English Economy, Teaching experiment

\begin{abstract}
With the rapid development of the world economy, English Economy course attracts more and more attention. How to teach English Economy course with large quantity of professional economic knowledge and train professionals with mastering international trade knowledge and foreign language knowledge is an urgent problem for teachers to solve. The game, as a supplementary teaching method, can be used to explain the profound in simple terms, live up the atmosphere and enhance the subjective participation. That will help improve teaching quality. With the introduction of game teaching method in the teaching of English Economy course and the application of "Vocabulary Game" and "Scenario Simulation Game", the author finds that game teaching has certain significance for English Economy course.
\end{abstract}

\section{Introduction}

Economic globalization and the accession to the World Trade Organization make the trade between China and WTO members closer and cooperation prospect broader. At the same time, it also makes us aware of the urgency to train a large number of international trade professionals particularly with economics awareness and foreign language knowledge. Based on the author's own experience in teaching English Economy course, the author concludes that the appropriate application of the game to the course teaching can not only maintain the students' interest and enthusiasm, but also improve the teaching quality.

\section{An Overview of Game Teaching Theory}

Game teaching method, also known as learning gamification, is carried out under the guidance of learning gamification concept to design and choose proper development tools, evaluation methods and teaching strategies by learning from games, which are based on training objectives, learners age, psychological characteristics and other aspects in the instructional design process. The key point of gamification learning is to give full play of educational games in teaching. Plato said:" we should live our life as a game." Jaspers declared:" people are constantly changing games that give physical and mental freedom by a variety of practice to look for answers to life. These self-overcoming and upgrading activities can be considered to listen to the law of life." The application of games to help people learn cultural knowledge and life skills has been in existence from ancient times. In Early 20th century, Jean Piaget, an American pragmatist philosopher and educator, emphasized the use of games in teaching to make children "learn from doing things and experience". He believed games and contests are the most suitable things to children's psychological characteristics. Children can find, analyze and solve problems in relaxing and lively activities to fully develop and apply their 
intelligence, which lays a philosophical foundation of game teaching. According to Krashen Stephen's "affective filter" hypothesis on language acquisition, language acquisition is a product of individual emotion filtration. In the language acquisition process, language and learning progress that cause individual negative emotions or unpleasant emotional experience will be sealed off the individual language memory system. The more filterable product, the more slowly that the individual receives, handle and digest the language system. It will even exclude language acquisition. Krashen Stephen also mentioned that anxiety, tension and vapidity are "affective filters". Therefore, in the teaching of the second language acquisition, teachers must weaken the function of "affective filter" and make teaching interesting and informative to inspire students' positive learning emotions, so that they can absorb knowledge positively in a pleasant environment.

With a thorough study of learners in foreign language teaching research, the migration effect of teaching diversity on teaching effectiveness attracts more attention. Classroom games will undoubtedly provide more possibilities for the diversity of foreign language teaching. As Richard Amato said," foreign language classroom games can ease the tension and pressure of the learning atmosphere, stimulate new language points and ideas and bring more choices to the traditional classroom.

\section{The Specific Application of Game Teaching Method in the Teaching of English Economy}

Experimental subjects and methods. Subjects: undergraduate sophomores in two classes that participate in this research. Methods: use contrast test, questionnaire survey, unit testing and other ways to collect relevant data. One unit uses game teaching method, while the other units apply the traditional teaching model.

Experimental contrasts. Vocabulary Game one: "Word Solitaire" game. Before the game, students are required to do prep work. In the classroom, teachers must divide students into groups first with 5-6 people in each group in general. The teacher give the first word, such as freight, and ask each student to write a word that begins with the letter "t", like tender. Then, write a word beginning with "r", such as ratio and so on. Within the specified time, the group which writes the most correct words wins. This game can fully stimulate students' ambition and make students review words effectively by helping each other.

Vocabulary Game two: "Finding a Partner" game. There are plenty of similar concepts in the World Trade English Course and students are easily confused by these concepts. This game gives students a platform to discriminate similar concepts well. Specific operation is following. First, teachers should prepare two envelopes marked A and B before class. Envelope A contains confusing conceptual phrases such as Absolute Advantage, Comparative Advantage, Opportunity Cost, Average Cost, Current Account, Capital Account, Counter Trade, barter Trade, Entrecote Trade, Transit Trade and so on. Envelope B includes corresponding explanations and examples of these phrases. It requires students to carry out some preview and have a better understanding of the meaning of conceptual phrases that they will encounter in the game. In the classroom, students are divided into even number groups with 7-8 students in a group. Then, distribute envelope A and B to students with half of the students get $A$ and the other half get B in one group. Afterwards, students with cards in Envelope A look for students holding corresponding cards in Envelope B. If students' foundation in this class is weak, teachers can make one word with one corresponding explanation when design the game. If students have a good understanding in this class, teachers can design words that have more correct corresponding explanations and related examples or cases. If students can not quite understand the card in their hands, they can ask help form other students to discuss with each other in English. In this game, Teacher should participate in each group to know students' 
mastery of conceptual phrases. Finally, the teacher announces the correct answer, makes some appropriate interpretation and praises the first team that finds right partners. By way of the game, students can discuss with each other to further consolidate their knowledge and correct misconceptions timely.

\section{Experimental Results and Discussion}

Game teaching helps to enhance students' cognitive level. Piaget believes that the game is characterized by assimilation exceeding naturalization form the view of the cognitive essence. That is to say that "students integrate information stimulated by the outside world with their original cognitive structure in the game design process to enhance the cognitive level." The questionnaire shows that $80 \%$ students agree with that "games can help them to have a better understanding and mastery of knowledge of international trade". 87\% think "the game can help them recognize that they need to improve their verbal communication and negotiation skills in international trade." These data illustrate the game can effectively help students understand theories and principles of international trade and apply these knowledge to simulative international trade negotiations.

Games are conducive to train and develop students' healthy learning emotion. Learning interest is the most active factor in learning, which can effectively stimulate students' intrinsic learning motivation, strengthen this motivation and mobilize students' learning initiative and creativity. The interesting game makes students enjoy learning when they absorb knowledge. The vast majority of students (93.4\%) declare that they like the game teaching method in international trade English classes. 85.6\% of the students believe that games stimulate their interest in learning and $92.9 \%$ say "the game reinforces learning knowledge in the class". It can be seen that to a certain extent, games can indeed stimulate students' interest in learning and improve students' learning emotion.

Games contribute to improve students' communicative level and oral expression ability. Game teaching provides a real communicative environment in the classroom and language returns to the position of communication tool in the natural state in the game. Survey results show that $86 \%$ of the students think that "they are more willing than ever to speak in class through the game". $96.6 \%$ of the students agree with that" the game promotes exchanges and cooperation between students". 82.7\% students go along with that "their oral expression ability has been improved to some extent". In addition, during the experiment, the author believes that game teaching should obey the following principles. First is the principle of purpose. All teaching activities in the classroom are designed based on teaching objectives and the game is no exception. We must focus on teaching content. The second is the principle of interest. The reason why the game teaching allows teachers and students to feel happy and mobilizes the students' enthusiasm and participation is that it contains the interesting features of the game. Third one is the principle of participation. The participation of game teaching embodies that it stimulates students' initiative, so that every student feel the joy of working with others. The fourth is the principle of discipline. The teacher must explain to students the rules of the game before doing it, so that the whole class is orderly and relaxing.

\section{Conclusion}

In summary, we find that applying appropriately designed games to International Trade English classes can stimulate students' learning interest to a certain extent and improve students' grasp of knowledge and the application of theories, thus improving teaching effectiveness and education 
quality in the classroom. Certainly, games methods designed by the author are just a tip of the iceberg of specific game application and there are more game teaching methods that need us to study and develop.

\section{References}

[1] Shao xian, Liu Xiafen. The Application of Game Teaching Method in the Teaching of International Trade English [J]. Journal of Zhejiang Ocean University (Humanities Science), 2012, 02: 89-92.

[2] Chen Xiaodong. A Discussion on Bilingual Teaching in Business English in International Trade Curriculum [J]. Foreign Economic Relation and Trade, 2011, 12: 150-151.

[3] Li Guo. Problems and Countermeasures in Bilingual Teaching - a Case Study of "International Trade Practice" [J]. Reform and Opening, 2009, 10: 215-216.

[4] Xie Guanghua. The Application of the Use of Progressive Bilingual Teaching in International Trade Courses [J]. Journal of Shanxi Institute of Economic Management, 2010, 03: 122-124.

[5] Liu Xiaopeng, Tian Wenhan, Teaching Reform of "International Trade Practice English" [J]. Machinery Vocational Education, 2010, 05: 59-60 + 63.

[6] Ruphina Anyaegbu, Wei Ting, Li Yi. A Research on the Application of Serious Games in ESL Teaching in Nigeria Elementary Schools [J]. Journal of Nanjing Xiaozhuang University, 2014, 06: $105-111$. 